\title{
Multiplex Immunofluorescence Analysis of Infiltrating Mononuclear Cell Subsets in Acute T-cell- mediated Rejection and Bk Virus-Associated Nephropathy in The Allograft Kidney
}

Yong-Jin Kim ( $\nabla_{\text {yyjjkim1@gmail.com ) }}$

Kyungpook National University Hospital

Jeong-Hoon Lim

School of Medicine, Kyungpook National University

Man-Hoon Han

Kyungpook National University Hospital

Mi Sun Kim

Kyungpook National University Hospital

\section{Sang-Yeob Kim}

Asan Medical Center

Yun Jae Kim

Asan Medical Center

\section{Research Article}

Keywords: laborious cell counting, cortex, virus-associated nephropathy, immunohistochemistry, light microscopically

Posted Date: August 17th, 2021

DOl: https://doi.org/10.21203/rs.3.rs-799112/v1

License: (c) (i) This work is licensed under a Creative Commons Attribution 4.0 International License. Read Full License 


\section{Abstract}

Transplant rejection has been diagnosed by mononuclear cell infiltration patterns light microscopically. Although infiltration involves different types of mononuclear cells, analysis of the rejection-associated variation was difficult by usual immunohistochemistry; one antibody staining on each slide and laborious cell counting. The authors applied the newly developed multiplex immunofluorescence staining(MIF) and image analysis system to overcome those disadvantages. By using formalin-fixed, paraffin-embedded slides of acute T-cell-mediated rejection (TCMR, 9 cases) and BK virus-associated nephropathy (BKVAN, 5 cases), the immunologic analysis was done because both had similar mononuclear cell infiltration patterns histologically. Antibodies to CD4, CD8, CD20, CD68, Foxp3, and cytokeratin were used.

The cellular subsets were similar to each other. CD68+ cells were dominant in the cortical interstitium. However, by using this method, we could find differences in cellular distributions in the area by area. In the medullary rays, albeit the location being in the cortex, cellular subsets were similar to those of the medulla. In areas surrounding large vessels thought of as non-diagnostic areas, the CD20+ cells were dominant.

This MIF could use as an ancillary method of diagnosis and follow up the cellular changes during rejection or treatment. Further large samples with rejection condition-matched studies should be followed.

\section{Introduction}

Renal allograft biopsy is the gold standard procedure in diagnosis of the kidney rejection via specific pathological changes. The major factor in the acute T-cell-mediated rejection (TCMR) is tissue infiltration of mononuclear cells. The TCMR severity depends on the percentage of interstitial area affected by the infiltration. ${ }^{1-3} \mathrm{~T}$ cells are known to be important in the pathogenesis of TCMR, although multiple other mononuclear cell subpopulations, including B cells, NK cells, plasma cells, and monocytes/macrophages, were shown to contribute to the outcome of the rejection-related immunologic events. ${ }^{4-7}$ However, the cell population analysis was complicated using traditional immunohistochemistry because of the limitation of multiple antibodies staining and human errors in cell counting. 8,9

To provide a better assessment of immunologic events in TCMR and BK virus-associated nephropathy (BKVAN) patients, we used multiplex immunofluorescence staining to identify infiltrating mononuclear cell subsets in the transplanted kidney in cortex areas. Because BKVAN had characteristic interstitial mononuclear cell infiltration and even tubulitis, which was one of the symbolic changes of acute TCMR. Those made it difficult to differentiate each other. Additionally, we tried to evaluate the differences in infiltrating cell subsets in the excluding areas for diagnosis even in the cortex such as fibrotic areas, the immediate subcapsular cortex, and adventitia around large vessels and medullary areas. ${ }^{1}$

\section{Material And Methods}




\section{Study design}

An immunohistochemical (IHC) analysis of formalin-fixed, paraffin-embedded tissues (FFPE) was conducted using samples from nine patients with acute TCMR and five patients with BKVAN at various time points after transplantation. All samples were collected between January 1, 2015 and December 1, 2017 at the department of pathology in Kyungpook National University Hospital and Yeungnam University Hospital in Daegu, Korea. The study protocol was approved by the Daegu Joint Institutional Review Board (DGIRB 2017-08-001) and informed consent was waived by Daegu Joint Institutional .Review Board. All methods were carried out in accordance with Korean Bioethics and Safety Act.

\section{Patient selection criteria and tissue pathology grading (Table 1,2)}

Table 1

Basic data of Acute TCMR cases.

\begin{tabular}{|c|c|c|c|c|c|c|}
\hline \multirow[t]{2}{*}{ Case } & \multirow[t]{2}{*}{ Age } & \multirow[t]{2}{*}{ Sex } & \multirow{2}{*}{$\begin{array}{l}\text { Graft Age } \\
\text { months }\end{array}$} & \multirow{2}{*}{$\begin{array}{l}\text { Creatinine } \\
\mathrm{mg} / \mathrm{dL}\end{array}$} & \multirow[t]{2}{*}{ Banff Score } & \multirow[t]{2}{*}{ Grade } \\
\hline & & & & & & \\
\hline 1 & 42 & $\mathrm{~F}$ & 3 & 1.8 & $\mathrm{i} 2, \mathrm{t} 3, \mathrm{ptc} 1, \mathrm{ti} 2$ & $1 \mathrm{~A}$ \\
\hline 2 & 33 & $M$ & 15 & 4.3 & $\mathrm{i} 2, \mathrm{t} 3, \mathrm{ptc} 1, \mathrm{ci} 2, \mathrm{ct} 2$ & 1B \\
\hline 3 & 40 & M & 9 & 4.4 & $i 3, t 3, v 2$ & $2 B$ \\
\hline 4 & 33 & M & 8 & 2.7 & $\mathrm{i} 2, \mathrm{t} 2, \mathrm{ptc} 1$ & $1 \mathrm{~A}$ \\
\hline 5 & 55 & M & 1 & 1.2 & $\mathrm{i} 2, \mathrm{t} 2, \mathrm{v} 2, \mathrm{ptc} 1$ & $2 \mathrm{~B}$ \\
\hline 6 & 56 & $\mathrm{~F}$ & 10 & 2.4 & $\mathrm{i} 2, \mathrm{t} 3, \mathrm{cv} 1$ & $1 \mathrm{~B}$ \\
\hline 7 & 58 & $M$ & 4 & 2.8 & $\mathrm{i} 3, \mathrm{t} 2, \mathrm{ptc} 1, \mathrm{ti} 3$ & $1 \mathrm{~A}$ \\
\hline 8 & 62 & $M$ & 8 & 2.4 & t1, v2, ptc1, ci1, ct1, ti2, i-IFTA3 & $2 B$ \\
\hline 9 & 42 & $\mathrm{~F}$ & 7 & 4.5 & $\mathrm{i} 3, \mathrm{t} 3, \mathrm{~g} 1, \mathrm{ci} 2, \mathrm{ct} 2, \mathrm{cv} 1, \mathrm{ah} 1, \mathrm{ti} 3$ & $1 \mathrm{~B}$ \\
\hline
\end{tabular}


Table 2

Basic data of BK virus nephropathy cases.

\begin{tabular}{|c|c|c|c|c|c|c|}
\hline \multirow[t]{2}{*}{ Case } & \multirow[t]{2}{*}{ Age } & \multirow[t]{2}{*}{ Sex } & \multirow{2}{*}{$\begin{array}{l}\text { Graft Age } \\
\text { months }\end{array}$} & \multirow{2}{*}{$\begin{array}{l}\text { Creatinine } \\
\mathrm{mg} / \mathrm{dL}\end{array}$} & \multirow[t]{2}{*}{ Banff Score } & \multirow[t]{2}{*}{ Stage } \\
\hline & & & & & & \\
\hline 1 & 62 & $M$ & 5.5 & 2.2 & ci1, ct1, cv1, i-IFTA1 & $\mathrm{B}$ \\
\hline 2 & 58 & $M$ & 2.5 & 1.8 & i3, t1, ptc1, ti3 & B \\
\hline 3 & 30 & $M$ & 7 & 1.8 & ci1, ct1, ti3 & $A$ \\
\hline 4 & 25 & $M$ & 4 & 3.3 & I2,ci1,ct1,ti3 & $\mathrm{B}$ \\
\hline 5 & 62 & M & 6.5 & 3.1 & i2, ptc1, ci2, ct3, ti3, i-IFTA3 & C \\
\hline
\end{tabular}

Inclusion criteria for acute TCMR $(n=9)$ were as follows: category 4 histologic features of acute TCMR based on the Banff 2017 classification system ${ }^{10}$, negativity for SV-40 cells based on IHC, absence of BK virus in serum or urine, and negativity for the donor-specific antibody. The male-to-female ratio of patients with TCMR was 6:3. The mean patient age and graft age were 46.8 [range, 33-62] years and 7.2 [1-15] months, respectively. Acute TCMR grades 1A, 1B, and 2B were observed in three different patients. Plasma cell rich type of TCMR was not included.

Inclusion criteria for BKVAN $(n=5)$ were as follows: histologic features of BKVAN with SV-40 positive cells in the cortex, clinical improvement in graft function with antiviral treatment after pathologic diagnosis, no histologic features of acute TCMR or ABMR, and $>500$ inflammatory cells in the cortical area. The male-to-female ratio for BKVN patients was 5:0. The mean patient and graft ages were 47.4 [25-62] years and 5.1 [2.5-7] months, respectively. According to the Banff Working Group Classification System ${ }^{11}$, one patient had class $A$, three- class $B$, and one-class $C$ diseases.

\section{Multiplex immunofluorescence (IF) staining}

FFPE blocks of renal biopsy specimens were cut into $2-\mu \mathrm{m}$ sections. The slides were heated for at least 1 hour in a dry oven at $60^{\circ} \mathrm{C}$ and dewaxed using Leica Bond Dewax (\#AR9222, Leica Biosystems). Then, multiplex immunofluorescence staining was performed using Leica Bond Rx Automated Stainer (Leica Biosystems, Newcastle, United Kingdom). Antigens were retrieved using Bond Epitope Retrieval 2 (\#AR9640, Leica Biosystems) in a solution at pH 9.0 for 30 minutes. The slides were incubated with primary antibodies for CD8 (MCA1817T, dilution 1:300; Bio-Rad Laboratories, Hercules, CA, USA) for 30 minutes and then analyzed using Polymer HRP Ms + Rb (ARH1001EA; PerkinElmer, Waltham, MA, USA) for 10 minutes. CD8 was visualized using Opal 690 TSA Plus (dilution 1:150; 10 minutes).

To remove bound antibodies before the next step staining in the sequence, the slide was treated with Bond Epitope Retrieval 1 (\#AR9961, Leica Biosystems) for 20 minutes. In a serial fashion, the slide was incubated with the next primary antibodies against Foxp3 (ab20034, dilution 1:100; Abcam, Cambridge, United Kingdom) for 30 minutes and analyzed using Polymer HRP Ms + Rb. Foxp3 was also visualized 
using Opal 650 TSA Plus (dilution 1:300; for 10 minutes). The same procedures were repeated for staining with anti-CD20 (ab9475, dilution 1:50; Abcam; visualized with Opal 620 TSA Plus (dilution 1:150)), anti-CD 68 (M0876, dilution 1:100; Dako, Santa Clara, CA; visualized with Opal 570 TSA Plus (dilution 1:150)), anti-CD4 (ab133616, dilution 1:100; Abcam; visualized with Opal 540 TSA Plus (dilution 1:300)), and anti-CK (M3515; dilution 1:500; Dako; visualized with Opal 520 TSA Plus (dilution 1:150)) immunoreagents.

After treatment with Bond Epitope Retrieval 1 for 20 minutes, cell nuclei were subsequently visualized with 4',6-diamidino-2-phenylindole (DAPI) stain, and the section was cover-slipped with HIGHDEF IHC fluoromount reagent (ADI-950-260-0025; Enzo Life Science, Inc., Farmingdale, NY, USA).

\section{Image acquisition and quantitative data analysis}

The slides were scanned using the PerkinElmer Vectra 3.0 Automated Quantitative Pathology Imaging System at 20-nm wavelength intervals from 420 to $720 \mathrm{~nm}$. The different depth images were combined to create a single stack image, which retained the unique spectral signature of all multiplex-IF markers. The final image files were created using Vectra and analyzed using InForm 2.2.1 and TIBCO Spotfire software (PerkinElmer). To compare reliable unmixed images, the representative images of each emission spectrum and unstained tissue slides were used. Each individually stained section (CD8-Opal 690, Foxp3Opal 650, CD68-Opal 620, CD20-Opal 570, CD4-Opal 540, CK-Opal520, and DAPI) was used to establish the spectral library of fluorophores required for multispectral analysis. Individual cells were identified by detecting nuclear spectral elements (DAPI).

For a co-expression analysis, the data obtained using InForm 2.2.1 were sent to TIBCO Spotfire, and the threshold for the positivity of each marker was determined using the $\mathrm{IHC}$ scoring method. For each antibody, all cells in each slide were counted (positive and negative), and the data were categorized and exported to an Excel file (Microsoft Corp., Redmond, WA, USA) for analysis.

The proportions of CD8-, Foxp3-, CD68-, CD20-, CD4-, and CK-positive cells in each region of interest (ROI) in each slide were calculated. The total number of positive cells was considered as the total immune cell infiltration in the tissue. The percentage of each immune cell subset was calculated by dividing the absolute number of each subset by the total number of cells.

\section{Categories of ROI (Fig. 1)}

The areas of ROI were defined as follows:

\section{cortical interstitium}

mononuclear cell infiltrated area in the renal cortex with no severe tubular atrophic or fibrotic changes; representative area for Banff score " $i$ "

\section{area surrounding large vessel}


mononuclear cell infiltrated area around veins, arteries, or lymphatics. The area was not considered to be not meaningful for assessment of Banff score "i."

\section{medullary ray}

The area with structures consisting of bundles of renal tubules which are formed in the renal cortex and continue to run through the renal medulla as the medullary striations. The area was not separated from cortical interstitium in Banff scoring.

\section{subcapsular area}

the areas immediately beneath the renal capsule, which may show nonspecific scarring or inflammation. The condition is thought to be related to surgical handling.

\section{Selection of ROI}

The rectangular ROls were marked on the scanned images acquired after multiplex immunofluorescence staining (Fig. 2). Positive and negative cell counting was performed independently within these ROls. Then, the total number in each ROI was assessed (Fig. 3). Any ROI with less than 100 cells of total were exclude.

We also attempted to estimate cell in tubulitis areas and peritubular capillaritis in this study using the same method. However, data was not considered as confusing because the indicated areas overlap with the surrounding interstitial area which contained infiltrating cells.

In acute TCMR cases $(n=9)$, cortical interstitium $(n=16)$, area surrounding a large vessel $(n=13)$, medullary ray $(n=8)$, medulla $(n=10)$, subcapsular area $(n=3)$ were selected for evaluation.

In BKVAN cases $(n=5)$, cortical interstitium $(n=12)$, area surrounding a large vessel $(n=3)$, medullary ray $(n=2)$, medulla $(n=3)$, and subcapsular area $(n=3)$ were selected for evaluation.

\section{Statistical analysis}

All variables were presented as median (interquartile range, IQR). The Kolmogorov-Smirnov test was used to analyze the normality of distribution. Student's $t$-test or the Mann-Whitney $U$ test was used to determine differences between continuous variables if it was appropriate. However, medullary ray $(n=2)$ and medulla $(n=3)$ from BKVAN, and subscapular area could not be used for statistical analysis or comparison to other areas, because of the small numbers of samples.

\section{Results}

The proportions of mononuclear cell subsets in different ROls are presented and compared in terms of various aspects of acute TCMR and BKVAN infiltrations (Table 3, Fig. 4,5) 
Table 3

Mean mononuclear cell subset numbers and ratios counted in regions of interest (ROI) and assessed using five monoclonal antibodies in nine cases of acute T-cell-mediated rejection (TCMR) and five cases of BK virus-associated nephropathy (BKVAN).

\begin{tabular}{|c|c|c|c|c|c|}
\hline Cases & TCMR & TCMR & TCMR & BKVAN & TCMR \\
\hline $\begin{array}{l}\text { ROI } \\
\text { category }\end{array}$ & $\begin{array}{l}\text { Interstitium } \\
(n=16)\end{array}$ & $\begin{array}{l}\text { Medullary ray } \\
(n=8)\end{array}$ & $\begin{array}{l}\text { Medulla } \\
(n=10)\end{array}$ & $\begin{array}{l}\text { Interstitium } \\
(\mathrm{n}=12)\end{array}$ & $\begin{array}{l}\text { Large Vessel } \\
(n=13)\end{array}$ \\
\hline Count & Median (IQR) & Median (IQR) & Median (IQR) & Median (IQR) & Median (IQR) \\
\hline CD68 & $\begin{array}{l}345.5 \\
(111.0-868.8)\end{array}$ & $\begin{array}{l}284.0 \\
(58.5-404.5)\end{array}$ & $\begin{array}{l}365.5 \\
(125.5- \\
1242.0)\end{array}$ & $\begin{array}{l}552.0 \\
(82.0-955.0)\end{array}$ & $\begin{array}{l}283.0 \\
(102.0-501.0)\end{array}$ \\
\hline CD8 & $\begin{array}{l}316.5 \\
(80.5-600.3)\end{array}$ & $\begin{array}{l}252.0 \\
(69.5-496.5)\end{array}$ & $\begin{array}{l}410.0 \\
(195.0- \\
1919.0)\end{array}$ & $\begin{array}{l}321.5 \\
(42.5-1041.0)\end{array}$ & $\begin{array}{l}322.0 \\
(132.0-691.5)\end{array}$ \\
\hline CD4 & $\begin{array}{l}8.0 \\
(1.0-30.8)\end{array}$ & $\begin{array}{l}0 \\
(0-160.3)\end{array}$ & $\begin{array}{l}43.0 \\
(5.0-147.3)\end{array}$ & $\begin{array}{l}61.0 \\
(2.3-697.5)\end{array}$ & $\begin{array}{l}2.0 \\
(0-51.5)\end{array}$ \\
\hline Foxp3 & $\begin{array}{l}39.5 \\
(4.8-69.8)\end{array}$ & $\begin{array}{l}32.5 \\
(11.0-55.3)\end{array}$ & $\begin{array}{l}27.5 \\
(7.5-285.8)\end{array}$ & $\begin{array}{l}21.0 \\
(3.5-623.3)\end{array}$ & $\begin{array}{l}49.0 \\
(19.5-109.5)\end{array}$ \\
\hline CD20 & $\begin{array}{l}137.0 \\
(27.5-476.0)\end{array}$ & $\begin{array}{l}370.0 \\
(11.5-488.0)\end{array}$ & $\begin{array}{l}209.5 \\
(26.8-423.8)\end{array}$ & $\begin{array}{l}329.5 \\
(39.5-689.8)\end{array}$ & $\begin{array}{l}210.0 \\
(69.5-872.0)\end{array}$ \\
\hline Total & $\begin{array}{l}902.5 \\
(276.8- \\
2117.5)\end{array}$ & $\begin{array}{l}1172.0 \\
(179.0- \\
1906.3)\end{array}$ & $\begin{array}{l}1127.0 \\
(304.3- \\
4583.8)\end{array}$ & $\begin{array}{l}1753.0 \\
(205.8- \\
4286.5)\end{array}$ & $\begin{array}{l}1111.0 \\
(374.5- \\
2171.0)\end{array}$ \\
\hline Ratio & Median (IQR) & Median (IQR) & Median (IQR) & Median (IQR) & Median (IQR) \\
\hline CD68 (\%) & $\begin{array}{l}41.8^{+9} \\
(31.7-46.9)\end{array}$ & $\begin{array}{l}21.2^{\dagger} \\
(19.3-30.9)\end{array}$ & $\begin{array}{l}36.8 \\
(21.0-42.8)\end{array}$ & $\begin{array}{l}40.1 \\
(23.4-48.7)\end{array}$ & $\begin{array}{l}26.9^{9} \\
(18.1-34.2)\end{array}$ \\
\hline CD8 (\%) & $\begin{array}{l}34.0^{\ddagger} \\
(24.7-45.1)\end{array}$ & $\begin{array}{l}38.2 \\
(18.3-41.8)\end{array}$ & $\begin{array}{l}41.2 \\
(30.3-46.2)\end{array}$ & $\begin{array}{l}22.8^{\ddagger} \\
(13.6-30.3)\end{array}$ & $\begin{array}{l}31.6 \\
(18.5-39.2)\end{array}$ \\
\hline
\end{tabular}

Continuous variables are shown as medians and interquartile ranges (IQR). Counts are presented as numbers and percentages. Variables were compared as means using Mann-Whitney-U test or the student's t-test; $\mathrm{n}=$ numbers of ROI.

Large Vessel indicates the area around large vessels; $\uparrow p<0.042$, $\neq p<0.07, \S p<0.04,9 p<0.012$, *p $<0.133$ 


\begin{tabular}{|c|c|c|c|c|c|}
\hline Cases & TCMR & TCMR & TCMR & BKVAN & TCMR \\
\hline $\begin{array}{l}\text { ROI } \\
\text { category }\end{array}$ & $\begin{array}{l}\text { Interstitium } \\
(\mathrm{n}=16)\end{array}$ & $\begin{array}{l}\text { Medullary ray } \\
(\mathrm{n}=8)\end{array}$ & $\begin{array}{l}\text { Medulla } \\
(n=10)\end{array}$ & $\begin{array}{l}\text { Interstitium } \\
(\mathrm{n}=12)\end{array}$ & $\begin{array}{l}\text { Large Vessel } \\
(n=13)\end{array}$ \\
\hline \multirow[t]{2}{*}{ CD4 (\%) } & $1.3^{*}$ & 0 & 1.7 & $3.4^{*}$ & 0.4 \\
\hline & $(0.2-6.6)$ & $(0-14.5)$ & $(0.7-21.7)$ & $(0.7-32.3)$ & $(0-1.8)$ \\
\hline \multirow[t]{2}{*}{ Foxp3 (\%) } & 2.7 & 2.5 & 4.0 & 1.7 & 5.7 \\
\hline & $(1.5-6.8)$ & $(1.3-20.1)$ & $(1.1-6.1)$ & $(1.2-15.7)$ & $(3.4-15.2)$ \\
\hline \multirow[t]{2}{*}{ CD20 (\%) } & $11.3 \S$ & 21.0 & 11.3 & 16.4 & $32.6 \S$ \\
\hline & $(3.7-23.1)$ & $(8.5-34.3)$ & $(5.2-16.8)$ & $(7.2-25.3)$ & $(18.8-41.8)$ \\
\hline \multicolumn{6}{|c|}{$\begin{array}{l}\text { Continuous variables are shown as medians and interquartile ranges (IQR). Counts are presented as } \\
\text { numbers and percentages. Variables were compared as means using Mann-Whitney-U test or the } \\
\text { student's t-test; } n=\text { numbers of ROI. }\end{array}$} \\
\hline \multicolumn{6}{|c|}{$\begin{array}{l}\text { Large Vessel indicates the area around large vessels; } \uparrow p<0.042, \neq p<0.07, \S p<0.04,9 p<0.012 \text {, *p } \\
<0.133\end{array}$} \\
\hline
\end{tabular}

\section{Cortical interstitium versus medullary ray in acute TCMR case (Table 3, Fig. 4)}

We assessed 16 areas in the cortical interstitium and 8 areas in the medullary ray in the cortex of patients with acute TCMR. In the interstitium, the most frequently observed cells were CD68 + cells $(41.8 \%$; IQR, 31.7-46.9\%), followed by CD8+, CD20+, Foxp3, and CD4+. In the medullary rays, the most frequently observed cells were CD8+ (38.2\%; IQR, 18.3-41.8\%), followed by CD68+, CD20+, Foxp3, and CD4 + cells. The proportion of CD68 + cells was significantly higher in the interstitium than in the medullary ray $(P<$ 0.042).

\section{Medullary ray versus medulla in acute TCMR cases (Table 3)}

We measured 10 areas in the medulla and compared them to the medullary ray. The proportion of mononuclear cell subsets was similar in these areas. CD8 + were the dominant cells, and the proportion of CD8 + cells was higher than that of CD $68+$ cells.

\section{Cell populations of interstitium in TCMR versus BKVAN samples (Table 3, Fig. 5)}

In BKVAN samples, the most frequently observed cells were CD68 + cells (40.1\%; IQR, 23.4-48.7\%), followed by CD8+, CD20+, CD4+, and Foxp3 + cells. A significant difference was observed in the 
percentage of CD8 + mononuclear cells. The level of CD8 + cells was higher in TCMR than that in BKVAN cases (34.0\%; IQR, $24.7-45.1 \%$ vs. $22.8 \%$; IQR, $13.6-30.3 \%$; $P<0.007$ ).

\section{Interstitium versus area surrounding large vessels (Table 3)}

CD20 + cells (32.6\%; IQR, 18.8-41.8\%) were most frequently observed among mononuclear cells in areas surrounding large vessels, and followed by CD8+, CD68+, Foxp3, and CD $4+$ cells. The proportion of CD20 + cells was higher in areas around large vessels, compared to the cortical interstitium of TCMR patients $(P<0.004)$. The ratio of CD68 + cells was significantly lower than that for TCMR $(P<0.012)$.

\section{Medullary ray and medulla in BKVAN cases (not shown in Table 3)}

CD8 $+(36.7 \pm 21.5 \%)$ were dominant in medullary ray and CD20+ $(40.8 \pm 20.0 \%)$ were major in medulla of BKVAN. However, because of small numbers of samples; medullary ray $(n=2)$, medulla $(n=3)$, those were not available for comparison.

Although CD20 + cells were the dominant subset in all these areas, the results were not statistically significant due to the insufficient number of samples

\section{Summary of significant changes in infiltrating cell populations}

In acute TCMR, CD68 + cells were dominant, although the proportions of CD68 + and T cells were similar (CD4 + plus CD8 + cells) in the cortical interstitium. The proportion of infiltrating leukocytes in the medullary ray was different from that in the cortical interstitium, although the rays are located in the cortical interstitium. CD $8+$ cells were the most dominant in those samples and followed by CD $68+$ cells. The proportion of CD68 + cells was higher in the cortex $(P<0.042)$ than in the medullary rays $(P<0.042)$. The infiltrating mononuclear cell subsets did not differ between the medullary rays and medulla.

Moreover, the interstitial infiltrating cells did not differ between acute TCMR and BKVAN. The CD68 + cells were found dominant in samples from both groups. However, the CD8 + cells were more prevalent in TCMR than in BKVAN patients $(P<0.007)$. The level of CD $4+$ cells was lower in TCMR than in BKVAN $(P<$ $0.133)$.

The proportion of infiltrating mononuclear cell subsets in areas surrounding large vessels was different from that in the cortical interstitium. CD20 + cells were dominant $(P<0.004)$, and the proportion of CD68 + cells was lower $(P<0.012)$ than that in the interstitium of TCMR.

\section{Discussion}

The multiplex immunostaining of TCMR samples showed that the most frequently observed cells were CD68 + cells than other types of lymphocytes. This has been suggested by using conventional IHC studies but we could prove it compositional analysis. The allorecognition is the first step in a sequence of 
complex events that lead to the T-cell activation, antibody production, and rejection. ${ }^{12,13}$ Several studies demonstrated the predominant occurrence of monocytes/macrophages in addition to $T$ cells using more advanced immunohistochemistry in TCMR cases. ${ }^{14-17}$ Girlanda et al. ${ }^{18}$ demonstrated that the large number of monocyte infiltration was quantitatively associated with renal dysfunction. High level of monocyte infiltration in rejecting allografts have been linked to the severe rejection, and glomerular monocyte infiltration has been suggested as an indicator of poor grafting outcome. ${ }^{19,20}$ Therefore, IHC monocyte and T-cells percentile measurements may be useful in assessment of acute clinical findings, especially considering graft biopsies. Consequently, the macrophage targeting agents had been considered as a rejection therapeutic option to improve the outcomes of transplant recipients. ${ }^{21,22}$

The medulla has been considered as the least specific region for rejection-induced injury. Medullary inflammation might be associated with different diseases, including pyelonephritis, interstitial nephritis, and others. ${ }^{23,24}$ However, Wang et al. ${ }^{25}$ suggested that medullary inflammation should not rule out a rejection because medullary inflammation may be a "spillover effect" of cortical lesions and the medulla has a lower rejection sensitivity (approximately $77 \%$ of that in cortex the) ${ }^{25}$ Sis et al. ${ }^{23}$ insisted that acute rejection-related lesions are more common and severe in the cortex, while the renal medulla does not sufficiently reflect the inflammation associated with the cortical rejection. The positive and negative predictive indicators of inflammatory changes in the medulla during the allograft rejection are insufficient. We also tested on the composition of infiltrating leukocyte subsets in medulla and medullary rays in acute TCMR, which are well-defined anatomic structures consisting of bundles of renal tubules. The bundles are formed in the renal cortex and continue to run through the renal medulla. The proportion of CD68 + cells in the medullary ray was significantly smaller than that in the cortical interstitium $(21.2 \%$ vs $41.8 \%, P<0.042)$. The proportions of mononuclear cell subsets in the medullary rays did not differ from that in the outer medulla. Therefore, the inflammatory markers in medullary ray or medulla cannot serve as reliable indicators of acute rejection changes. Furthermore, other causes that may be involved in initiation of the medullary inflammation should be ruled out before accepting that this inflammation is associated with the cortical rejection histology. Because medullary rays are located in the cortex, the structure was suggested to be a reliable area for inflammation-linked diagnoses and estimation of the infiltration intensity using Banff scores. Our results suggest that it necessary to assess the proportion of medullary ray inflammation in the Banff score chart, especially if the proportion is larger than usual in the biopsy specimens.

BKVAN diagnosis has been derived from histological assessments of lymphocytic interstitial infiltrates and the nuclear reaction to the anti-SV-40T antibody, a marker of viral replication. ${ }^{2,7}$ Notably, BKVAN diagnosis is difficult to differentiate from the acute TCMR. Our data indicates that mononuclear cell subsets in BKVAN samples did not differ from those of acute TCMR. The most frequently observed cells in both types of complications were CD $68+$ cells (BKVAN: $41.8 \%$ vs TCMR: $40.1 \%, P>0.705$ ). The second most abundant cells were CD $8+$ mononuclear cells, but the percentage of CD $8+$ was lower in BKVAN samples than that in TCMR $(34.0 \%$ vs. $22.8 \%, P<0.007)$. According to these results, we assumed that the strength of leukocyte attack and the associated renal damage may be less pronounced in BKVAN

Page $10 / 16$ 
compared to TCMR. However, larger investigation is required to confirm the differences between the two diagnoses using the multiplex immunohistochemistry method.

According to the Banff guidelines update of 1997, assessment areas that should be excluded from Banff lesion scoring include "fibrotic areas, immediate subcapsular cortex, adventitia around large veins, and lymphatics." ${ }^{\text {1,3,6,7 }}$ However, differences between inflammatory cell subsets in those areas and non-scarred cortical areas have not been investigated. We detected differences between cell subset composition in areas near large vessels $(n=16)$ from the cortical interstitium in TCMR cases. CD $20+$ cells $(32.6 \%)$ were the most frequently observed mononuclear cells, although not associated with TCMR effects. We also counted mononuclear cells in subcapsular area $(n=3)$. Although CD20 + cells were the dominant subset in all these areas, the results were not statistically significant due to the insufficient number of samples.

In summary, this MIF was useful for analysis of mononuclear cell subsets in renal allograft biopsy. The most frequent cell in the cortical interstitium of acute TCMR were CD68 + macrophages or monocytes rather than T cells. Those may contribute to allograft damage in the course of rejection. BKVAN could not differentiate from TCMR by this MIF, because both had similar cellular infiltration subsets. However, this MIF would be useful to follow up on the immunologic environmental changes in the allograft because these cellular proportions may be changed during the course of rejection or treatment. We could find differences in cellular distributions in the area by area. In areas surrounding large vessels thought of as non-diagnostic areas, the CD20 + cells were dominant. In the medullary rays, albeit the location being in the cortex, cellular subsets were similar to those of the medulla. Therefore, the proportion of medullary ray in the cortical interstitium should be considered for Banff " $i$ " scoring because cellular proportion in which were different from those of real cortical interstitium and the same to those of the medullary area.

\section{Declarations}

\section{Author contribution}

Y.J.K.: Conceptual and experimental design, Data analysis, Paper writing. J.H.L.: Data analysis. M.H.H.: Sample Collection, ROI Selection, Data analysis. M.S.K.: Sample Collection, Data analysis. S.Y.K.: MIF staining, Data analysis. Y.J.K.: MIF staining, Data analysis.

\section{Funding}

This work was supported by Biomedical Research Institute grant from Kyungpook National University Hospital (2017).

\section{Competing interests}

The authors declare no competing interests.

\section{References}


1. Racusen, L. C. et al. The Banff 97 working classification of renal allograft pathology. Kidney Int, 55, 713-723 (1999).

2. Hirsch, H. H. et al. Polyomavirus-associated nephropathy in renal transplantation: interdisciplinary analyses and recommendations., 79, 1277-1286 (2005).

3. Loupy, A. et al. The Banff 2015 Kidney Meeting Report: Current Challenges in Rejection Classification and Prospects for Adopting Molecular Pathology. Am J Transplant, 17, 28-41 (2017).

4. Platt, J. L., LeBien, T. W. \& Michael, A. F. Interstitial mononuclear cell populations in renal graft rejection. Identification by monoclonal antibodies in tissue sections. J Exp Med, 155, 17-30 (1982).

5. Kolbeck, P. C., Tatum, A. H. \& Sanfilippo, F. Relationships among the histologic pattern, intensity, and phenotypes of T cells infiltrating renal allografts., 38, 709-713 (1984).

6. Sako, H. et al. Immunohistochemical study of the cells infiltrating human renal allografts by the ABC and the IGSS method using monoclonal antibodies., 44, 43-50 (1987).

7. Waltzer, W. C., Miller, F., Arnold, A., Anaise, D. \& Rapaport, F. T. Immunohistologic analysis of human renal allograft dysfunction., 43, 100-105 (1987).

8. Hofman, P. et al. Multiplexed Immunohistochemistry for Molecular and Immune Profiling in Lung Cancer-Just About Ready for Prime-Time?Cancers (Basel)11(2019).

9. Mani, N. L. et al. Quantitative assessment of the spatial heterogeneity of tumor-infiltrating lymphocytes in breast cancer. Breast Cancer Res, 18, 78 (2016).

10. Haas, M. et al. The Banff 2017 Kidney Meeting Report: Revised diagnostic criteria for chronic active T cell-mediated rejection, antibody-mediated rejection, and prospects for integrative endpoints for next-generation clinical trials. Am J Transplant, 18, 293-307 (2018).

11. Nickeleit, V. et al. The Banff Working Group Classification of Definitive Polyomavirus Nephropathy: Morphologic Definitions and Clinical Correlations. J Am Soc Nephrol, 29, 680-693 (2018).

12. Ponticelli, C. The mechanisms of acute transplant rejection revisited. J Nephrol, 25, 150-158 (2012).

13. Whitelegg, A. \& Barber, L. D. The structural basis of T-cell allorecognition., 63, 101-108 (2004).

14. Halloran, P. F. Immunosuppressive drugs for kidney transplantation. N Engl J Med, 351, 2715-2729 (2004).

15. von Willebrand, E. et al. Composition and in vitro cytotoxicity of cellular infiltrates in 16., Role of macrophages in allograft rejection. Transplant Proc.; 11, 811-815(1979).rejecting human kidney allografts. Cell Immunol 41, 358-372 (1978).

16. Dy, M. et al. Role of macrophages in allograft rejection. Transplant Proc.; 11, 811-815(1979).

17. Hancock, W. W., Thomson, N. M. \& Atkins, R. C. Composition of interstitial cellular infiltrate identified by monoclonal antibodies in renal biopsies of rejecting human renal allografts., 35, 458-463 (1983).

18. Girlanda, R. et al. Monocyte infiltration and kidney allograft dysfunction during acute rejection. $A m \mathrm{~J}$ Transplant, 8, 600-607 (2008).

19. Magil, A. B. Monocytes/macrophages in renal allograft rejection. Transplant Rev (Orlando), 23, 199208 (2009). 
20. Sablik, K. A., Jordanova, E. S., Pocorni, N., Clahsen-van Groningen, M. C. \& Betjes, M. G. H. Immune Cell Infiltrate in Chronic-Active Antibody-Mediated Rejection. Front Immunol, 10, 3106 (2019).

21. Li, J. et al. The Evolving Roles of Macrophages in Organ Transplantation. J Immunol Res 2019, 5763430 (2019).

22. Kopecky, B. J. et al. Role of donor macrophages after heart and lung transplantation. Am J Transplant, 20, 1225-1235 (2020).

23. Sis, B. et al. Renal medullary changes in renal allograft recipients with raised serum creatinine. J Clin Pathol, 59, 377-381 (2006).

24. Bonsib, S. M., Reznicek, M. J. \& Wright, F. H. Renal medulla in the diagnosis of acute cellular rejection., 48, 690-692 (1989).

25. Wang, $\mathrm{H}$. et al. The renal medulla in acute renal allograft rejection: comparison with renal cortex. Nephrol Dial Transplant, 10, 1428-1431 (1995).

\section{Figures}
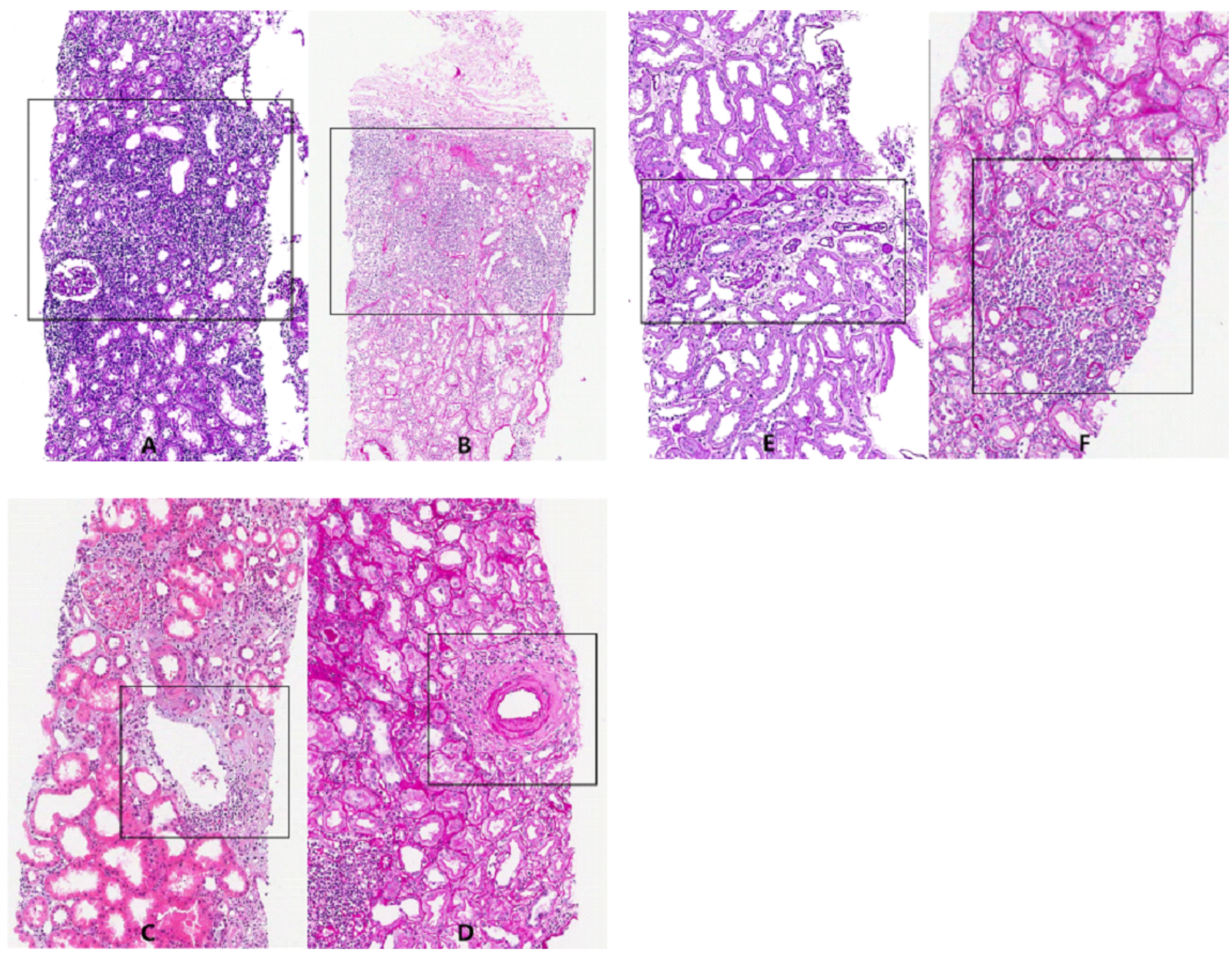


\section{Figure 1}

Representative areas of 'Regions of Interest (ROI)'. A), cortical interstitial infiltration area; B) subcapsular area; C), surrounding the vein; D), adventitia area of atery; E)F), medullary ray, longitudinal and cross section view.

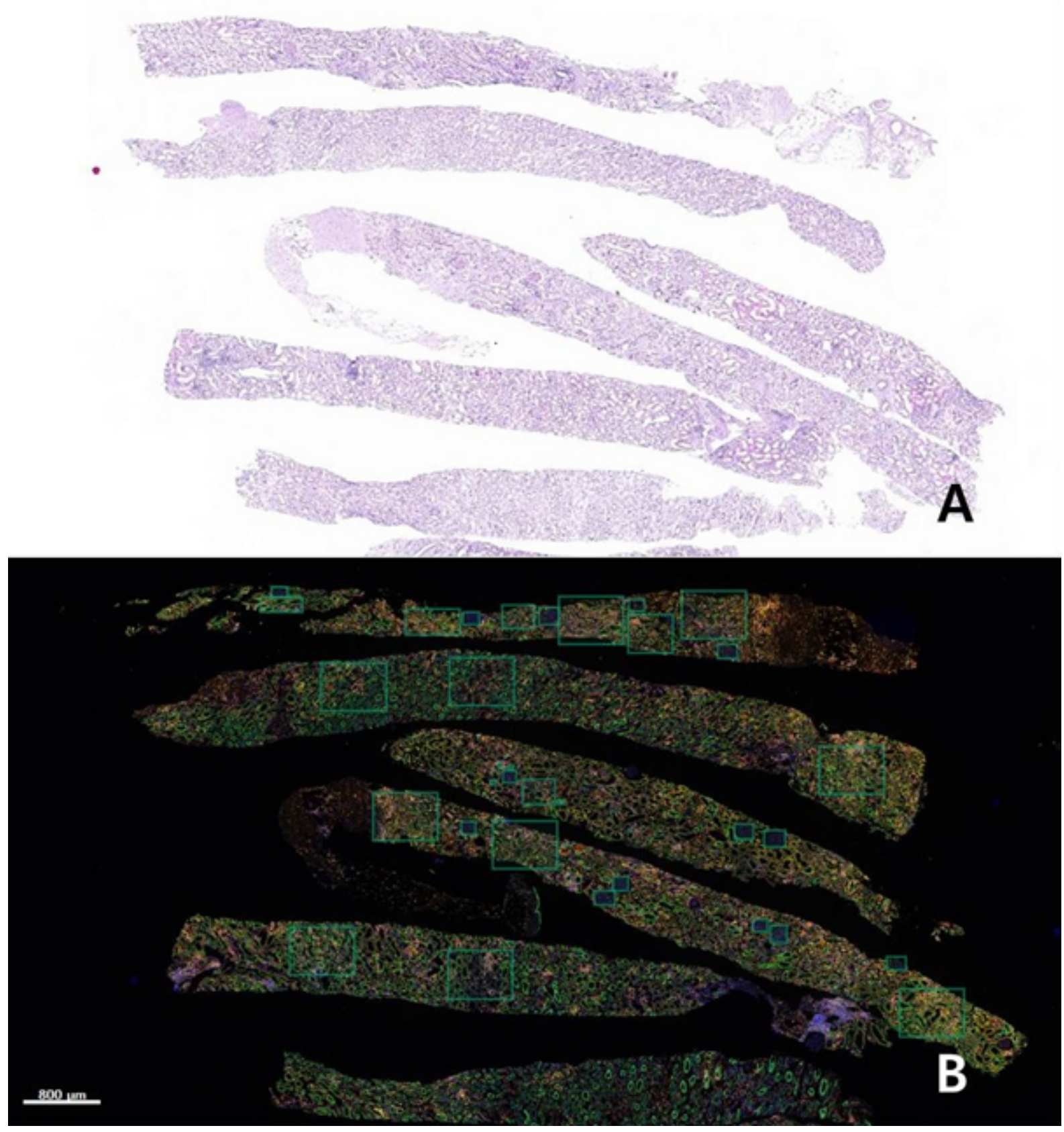

\section{Figure 2}

Selection of regions of interest (ROI). A. Acute T-cell-mediated rejection samples were stained with PAS. B. The scanned images show multiplex immunofluorescence staining. ROIs are marked with rectangles. Cell counting was independently performed within these ROls. The total number of cells was assessed per each ROI. 


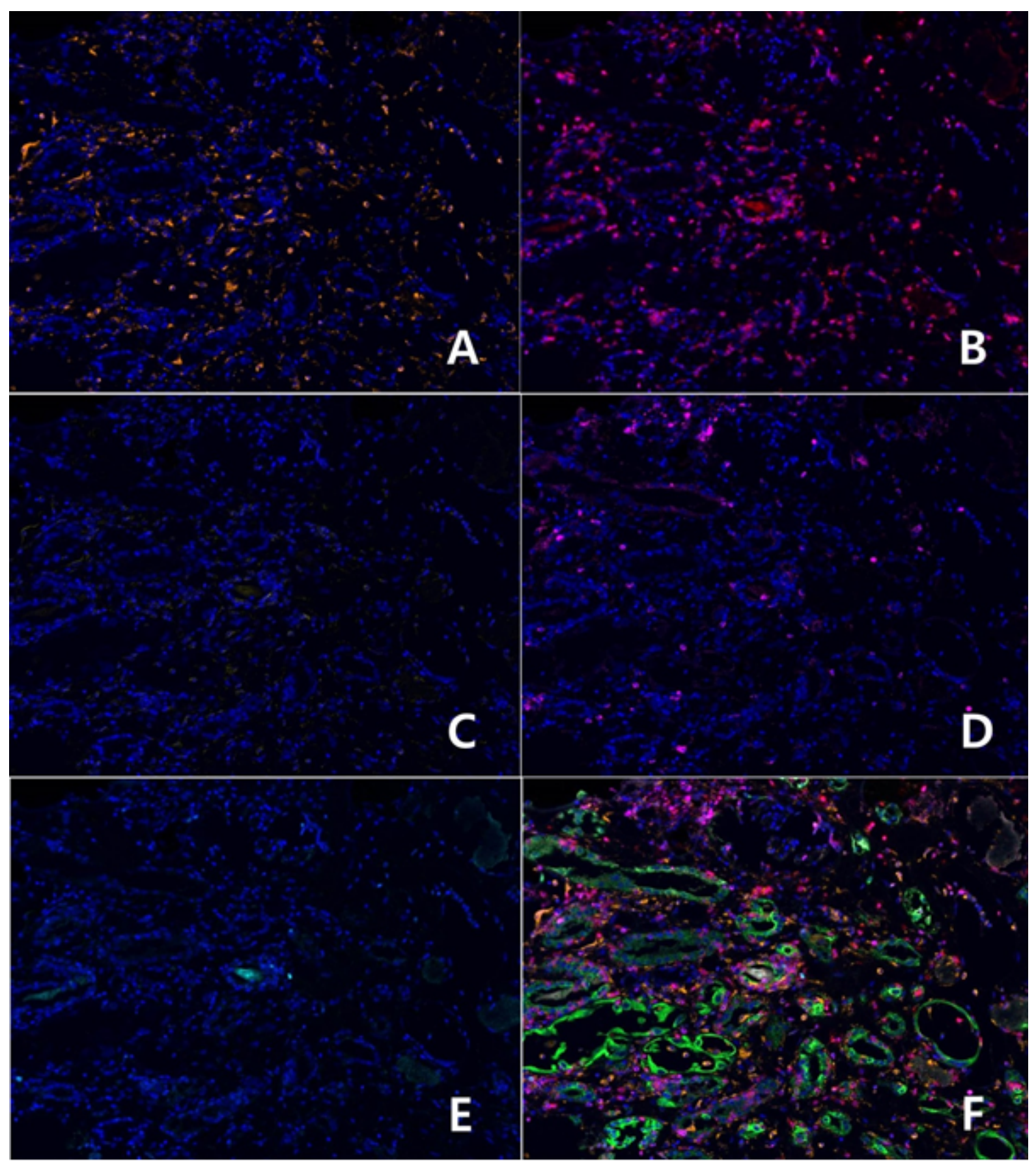

\section{Figure 3}

Multiplex immunofluorescent images show the individual antibody staining as follows: A) CD68+, B) CD8+, C) CD20+, D) CD4+, E) Foxp3+. F) All listed antibody staining was merged with Cytokeratin (CK) staining. Blue nuclear stain represents 4',6-diamidino-2-phenylindole (DAPI). 


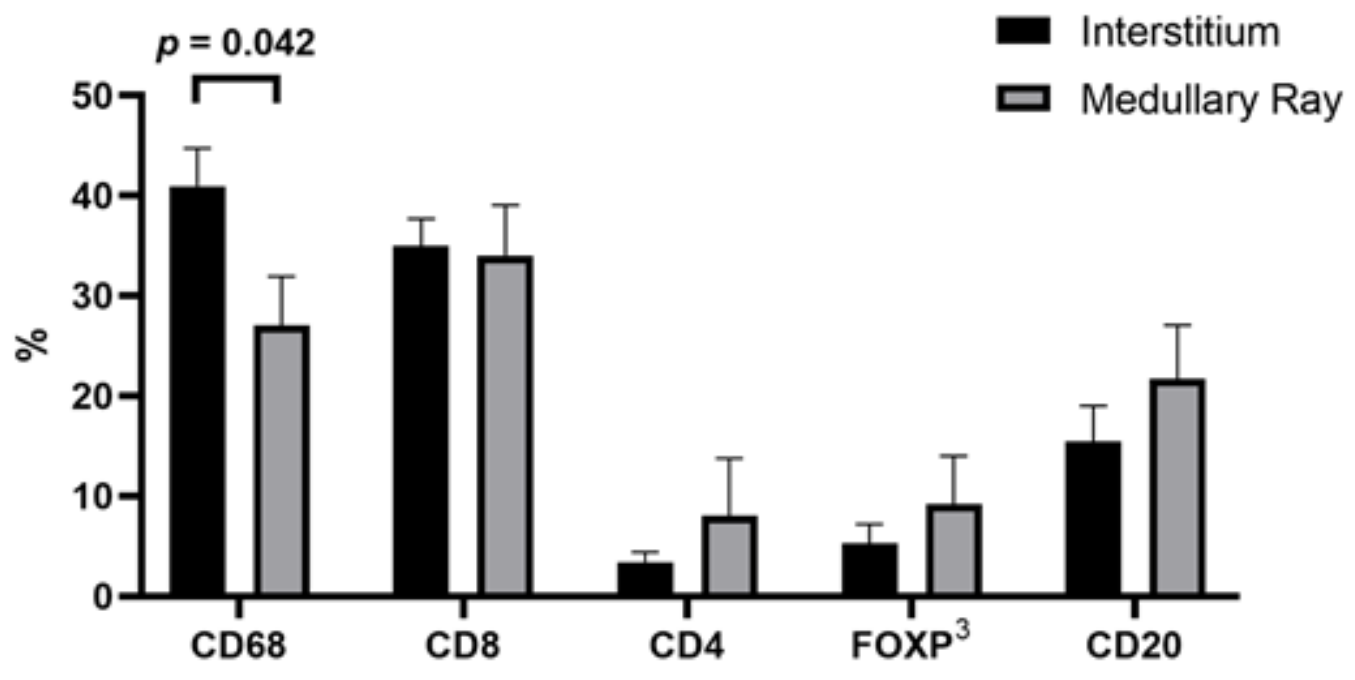

Figure 4

Comparison of mononuclear cell subset ratios between cortical interstitium and medullary ray areas using five types of monoclonal antibodies ( $\mathrm{X}$ axis) in nine TCMR cases. The proportion of CD68+ cells was significantly higher in the interstitium than in the medullary ray $(P<0.042)$.

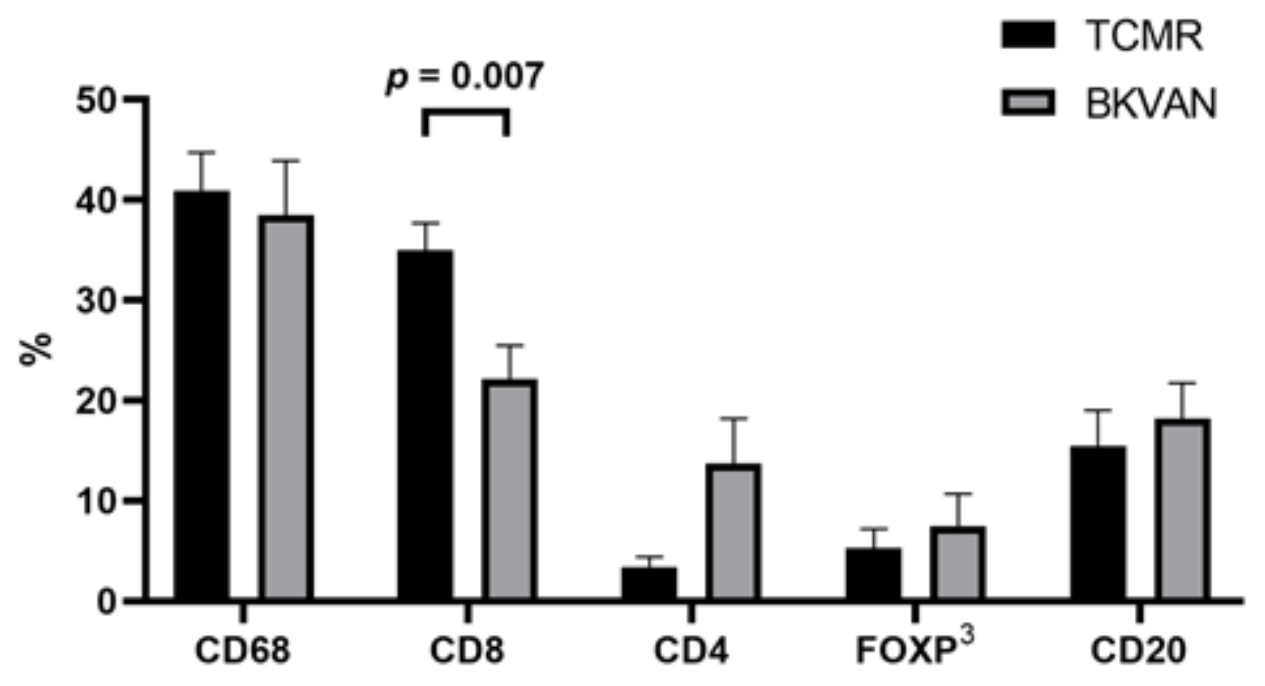

Figure 5

Means of mononuclear cell subset ratios in cortical interstitium. Tissues were stained using five types of monoclonal antibodies ( $X$ axis) in nine TCMR cases and five BKVAN cases. The percentage of CD8+ mononuclear cells was significantly higher in TCMR than in BKVAN cases $(P<0.007)$. 